\title{
Pengaruh Lama Perendaman Dengan Menggunakan Sari Jahe Terhadap Kualitas Fisik (Daya Ikat Air, Keempukan Dan Ph ) Daging Domba
}

\author{
Rikma Suantika $^{1 \mathrm{a}}$, Lilis Suryaningsih ${ }^{1}$, Jajang Gumilar ${ }^{1}$ \\ ${ }^{1}$ Fakultas Peternakan Universitas Padjadjaran \\ a email:Rikma1234@gmail.com
}

\begin{abstract}
Abstrak
Daging domba umumnya dikonsumsi dalam bentuk olahan. Ketersedian daging domba dapat ditingkatkan namun daging domba dari ternak yang berumur tua masih belum dapat sepenuhnya diterima masyarakat karena dagingnya alot. Hal ini perlu diperkenalkan teknologi untuk meningkatkan kualitas fisik daging domba tersebut. Salah satunya yaitu dengan perendaman dengan menggunakan sari jahe. Penelitian ini bertujuan untuk mengetahui pengaruh berbagai lama perendaman sari jahe pada daging domba terhadap daya ikat air, keempukan dan pH. Penelitian dilakukan secara eksperimental menggunakan Rancangan Acak Lengkap (RAL), dengan 3 perlakuan yaitu perendaman daging menggunakan sari jahe selama 10, 20 dan 30 menit. Masing-masing perlakuan diulang sebanyak 6 kali. Analisis varian digunakan untuk menentukan pengaruh lama perendaman sari jahe terhadap kualitas fisik, sedangkan perbedaan antar perlakuan digunakan Uji Jarak Berganda Duncan. Hasil penelitian menunjukkan bahwa berbagai lama waktu perendaman sari jahe pada daging domba berpengaruh nyata terhadap daya ikat dan air keempukan. Lama waktu perendaman selama 30 menit memberikan hasil yang paling optimum terhadap kualitas fisik daging domba.
\end{abstract}

Kata kunci: Jahe, Daging Domba, Perendaman, Kualitas Fisik

\section{The Effect Of Soaking Time Use Ginger Juice To Sheep Meat Physical Quality (Water Holding Capacity, Tenderness And Ph)}

\begin{abstract}
Sheep meat is generally consumed in processed form. The availability of sheep meat can be improved but the sheep meat from old sheep still can not be fully accepted by the people because the meat is tough. It is need to introduce technology to increase the physical quality of the sheep meat. One of them is by soaking using ginger juice. The aims of this research were to determine the soaking effect of sheep meat in the ginger juice with different duration on the physical quality such as water holding capacity (WHC), tenderness and $p H$. This research has carried out experimentally using a Completed Randomized Design (CRD), with three treatments in soaking of ginger juice at 10, 20 and 30 minutes. Each treatments was repeated six times. Analysis of variance was used to determine the effect of soaking time use ginger juice for aspect of physical quality (water holding capacity, tenderness and $p H)$ to sheep meat, whereas the difference between the treatment used Duncan's Multiple Range Test. The result have shown that soaking of sheep meat in ginger juice had significant effect on tenderness and WHC. The soaking duration of 30 minutes ginger juice give the most optimum result to physical quality of sheep meat.
\end{abstract}

Keywords: Ginger, Sheep Meat, Soaking, Physical Quality.

\section{Pendahuluan}

Daging adalah bagian otot skeletal dari karkas kambing/domba yang aman, layak dan lazim, dikonsumsi oleh manusia, dapat berupa daging segar, daging segar dingin atau daging beku (Badan Standardisasi Nasional, 2008). Ciri-ciri daging domba yaitu terdiri serabut halus, warna merah muda, banyak lemak diotot, bau sangat khas dan lemak berwarna putih. Komposisi nilai gizi yang terdapat pada daging domba yaitu terdiri protein $17,1 \%$ dan lemak 14,8 \% (Tien, dkk., 2011). Salah satu faktor yang mempengaruhi keempukan daging adalah umur ternak.

Daging dari ternak berumur muda lebih empuk dibandingkan dengan daging dari ternak berumur tua karena adanya perbedaan ukuran dan serabut daging. Tingkat keliatan jaringan ikat semakin meningkat pada ternak berumur tua, hal ini mengakibatkan tingkat 
keempukan daging menurun (Roswita dan Usmiati, 2009). Bagian daging juga dapat mempengaruhi keempukan. Bagian paha termasuk alat gerak, dimana ototnya sering digerakan atau bekerja aktif. Lokasi otot dapat menentukan keempukan otot tersebut. Kadar kolagen sebagai penyususun jaringan ikat otot mempengaruhi kealotan atau keempukan daging, otot yang aktif akan menghasilkan daging yang lebih alot daripada otot yang kurang aktif (Purbowati, dkk., 2006).

Banyak cara yang dilakukan dengan tujuan untuk memperbaiki kualitas daging, salah satunya yaitu perebusan daging sebelum pemasakkan, hal ini bertujuan untuk memperoleh daging yang empuk, tetapi bila terlalu lama direbus, kandungan nutrisi dalam daging akan terdenaturasi atau rusak, untuk itu diperlukan pengolahan dengan cara lain yang lebih efektif dan efesien. Salah satunya yaitu dengan metode perendaman. Metode perendaman dapat dilakukan dengan bahan berasal dari tanaman yang mengandung enzim proteolitik. Enzim proteolitik adalah enzim yang bekerja sebagai katalis dalam reaksi pemecahan molekul protein dengan cara hidrolisis (Anna dan Supriyanti, 2009).

Jahe dapat dijadikan sebagai perendam yang dapat memperbaiki kualitas daging karena jahe mengandung enzim protease yang dapat melunakkan daging. Jahe merupakan sumber protease yang memiliki rendemen 2,3 $\%$ atau 176 kali lebih banyak dari pada papain, enzim papain memiliki rendemen yang lebih rendah yaitu $0.013 \%$. Enzim protease yang terkandung dalam jahe disebut zingibain. Meningkatnya keempukan daging oleh enzim protease disebabkan oleh terdegradasinya protein (Thompson, dkk., 1973).

Jahe merupakan salah satu dari rempah-rempah yang biasa digunakan sebagai bumbu masak, selain itu pemberi aroma dan rasa pada makanan serta minuman, industri obat, minyak wangi dan jamu tradisional. Terdapat dua zat penyusun utama yang terdapat di dalam jahe yaitu minyak atsiri dan oleoresin. Minyak atsiri memberikan aroma harum sedangkan oleoresin memberikan rasa pedas. Oleoresin jahe banyak mengandung komponen pembentuk rasa pedas yang tidak menguap, terdiri atas gingerol, zingiberen, shagaol, minyak jahe dan resin. Jahe memiliki zat aktif yang terdapat pada minyak volatil (minyak atsiri) yang mempunyai komposisi 0,25\%-3,3\% dari bobot (Tien, dkk., 2011).
Selain keempukan, faktor $\mathrm{pH}$ berperan dalam penentuan kualitas daging. Nilai $\mathrm{pH}$ dalam otot $(\mathrm{pH}$ daging) setelah hewan disembelih (mati), akan menurun akibat adanya akumulasi asam laktat. $\mathrm{pH}$ daging tidak dapat diukur segera setelah pemotongan (kematian) (Soeparno, 2005). Salah satu cara dalam memperbaiki nilai $\mathrm{pH}$ adalah penambahan sari jahe. Jahe mengandung enzim proteolitik yang dapat menggunakan ion $\mathrm{H}^{+}$untuk penyediaan sumber energi pada proses glikolisis sehingga bisa menghambat pembentukan asam laktat dan nilai $\mathrm{pH}$ bisa meningkat. Kapasitas mengikat air merupakan faktor mutu yang penting karena berpengaruh langsung terhadap pengerutan daging, dengan perendaman sari jahe, diharapkan dapat meningkatkan daya ikat air daging domba tersebut dimana enzim protease masuk ke dalam jaringan miofibril daging maka akan terjadi proses hidrolisis lalu terjadi peningkatan kadar asam amino sehingga nilai daya ikat air meningkat. Tujuan penelitian ini adalah untuk mengetahui pengaruh lama perendaman dan lama waktu perendaman dengan menggunakan sari jahe terhadap kualitas fisik (daya ikat air, keempukan dan $\mathrm{pH}$ ) daging domba.

\section{Materi Dan Metode \\ Materi Penelitian}

Bahan utama yang digunakan dalam peneltian ini adalah $4 \mathrm{~kg}$ daging domba lokal jantan yang berumur 3 tahun bagian paha. Jahe Gajah yang berumur 8 bulan sebanyak $3 \mathrm{~kg}$. Aquades sebagai pelarut sebanyak 9 liter.

\section{Alat Penelitian}

Alat yang digunakan dalam penelitian adalah wadah platik, pisau, talenan, label, cup plastik, kalkulator, parutan, penetrometer, mortar dan alu, $\mathrm{pH}$ meter, kertas saring, plat kaca, beban seberat $35 \mathrm{~kg}$, mistar dan pensil.

\section{Pelaksanaan Penelitian}

\section{Pembuatan Sari Jahe}

Proses pembuatan sari dimulai dengan menyiapkan alat dan bahan yang diperlukan selama penelitian. Alat-alat dipersiapkan dalam keadaan bersih dan kering. Proses pembuatan sari jahe dibuat berdasarkan metode yang digunakan oleh Lilis, dkk., (2012). Pertama-tama rimpang jahe dicuci dengan bersih dan ditiriskan, kemudian dikupas kulitnya selanjutnya diparut serta disaring. 
Pembuatan konsentrasi larutan sari jahe menggunakan rumus dasar berdasarkan volume per volume $(\mathrm{v} / \mathrm{v})$. Perhitungan volume larutan sari jahe menggunakan rumus sebagai berikut :

$\mathrm{V}_{1} \cdot \mathrm{C}_{1}=\mathrm{V}_{2} \cdot \mathrm{C}_{2}$

Keterangan :

$\mathrm{V}_{1}=$ volume larutan sari jahe murni (konsentrasi $100 \%$ )

$\mathrm{C}_{1}=$ Konsentrasi larutan sari jahe murni (100 $\%)$

$\mathrm{V}_{2}=$ Volume larutan sari jahe yang akan dibuat

$\mathrm{C}_{2}=$ Konsentrasi larutan sari jahe yang akan dibuat

Pembuatan larutan sari jahe konsentrasi $15 \%$ diperoleh dengan cara mengambil $600 \mathrm{ml}$ larutan sari jahe murni kemudian ditambahkan aquades sebanyak $3400 \mathrm{ml}$.

\section{Perendaman Daging Domba}

Daging domba bagian paha direndam sari jahe dengan konsentrasi $15 \%$ selama 10 menit, 20 menit dan 30 menit. Daging domba bagian paha ditiriskan, kemudian dilakukan pengujian uji fisik (daya ikat air, keempukan dan $\mathrm{pH})$.

\section{Pengukuran Variabel}

1. Daya Ikat Air

DIA oleh protein daging dapat ditentukan dengan berbagai cara, antara lain dengan metode Hamm (Soeparno, 2005). Prosedur kerja pegujian daya ikat air dimulai dengan menimbang sampel sebanyak 0,3 gram, kertas saring disiapkan dan diletakan sampel diatasnya, sampel diletakkan di antara 2 plat kaca yang diberi beban $35 \mathrm{~kg}$ selama 5 menit, area pada kertas saring yang tertutup sampel daging yang telah pipih (area lingkaran dalam) dan keseluruhan area basah disekelilingnya (area lingkaran luar), luas area basah dapat diperoleh dengan mengurangkan area yang tertutup daging dari total area yang terbentuk pada kertas saring. Menghitung kandungan air yang keluar dari daging setelah penekanan dihitung dengan rumus:

$\mathrm{Mg} \mathrm{H}_{2} \mathrm{O}=\frac{\text { luas area basah }\left(\mathrm{cm}^{2}\right)}{0,0948}-8,0$

Menentukan kadar air dengan metode pengeringan sebagai persen kehilangan berat bahan, pengujian ini mengacu pada metode yang telah dilakukan oleh Tien, dkk., (2011).
Prosedur pengukuran kadar air, yaitu ; Cawan dikeringkan dalam oven dengan suhu $135^{\circ} \mathrm{C}$ selama 30 menit, Cawan didinginkan dalam desikator selama 15 menit, dan ditimbang (W1), Sampel daging sebanyak 5 gr ditimbang dalam cawan (W2) yang selanjutnya dikeringkan dalam oven dengan suhu $125^{\circ} \mathrm{C}$ selama $2-4$ jam sampai diperoleh berat yang tetap, Cawan berisi sampel didinginkan dalam desikator dan kemudian ditimbang (W3)

Kadar air $(\%)=\frac{\mathrm{W} 2-\mathrm{W} 3}{\mathrm{~W} 2-\mathrm{W} 1} \times 100 \%$

Menghitung daya ikat air (DIA) daya ikat air (DIA) dihitung dengan menggunakan rumus :

Daya ikat air $($ DIA $)=\%$ kadar air $-\frac{\mathrm{mg} \mathrm{H}_{2} \mathrm{O}}{300 \mathrm{mg}} \mathrm{x}$ $100 \%$

\section{Keempukan}

Pengujian keempukan dilakukan menggunakan alat penetrometer. Pengujian ini mengacu pada metode yang digunakan oleh Tien, dkk., (2011). Pertama-tama Sampel disiapkan dengan cara daging dipotong dengan ukuran $(5 \times 3 \times 2) \mathrm{cm}$. Daging diletakkan pada bagian dasar penetrometer. Jarum penunjuk diatur sehingga permukaan daging bersinggungan dengan ujung jarum, jarum penunjuk menunjukkan angka nol. Penusukan dilakukan sebanyak 10 kali pada 10 tempat. Hasil setiap penusukan ditunjukkan dengan angka pada skala penetrometer. Waktu yang diperlukan untuk penekanan maksimum terhadap bahan dapat ditentukan dengan menggunakan stopwatch selama 10 detik. Keempukan dapat diketahui dengan membaca angka pada skala yang terdapat pada alat. Nilai keempukan yang didapat diberi satuan $\mathrm{mm} /$ detik/gram. Semakin besar angka yang ditunjukan, maka daging semakin empuk. Hitung hasil perhitungan dengan menggunakan rumus :

Keempukan ( $\mathrm{mm} / \mathrm{gram} / 10$ detik) $=\underline{\text { rata-rata pengukuran }}$ 10 detik

\section{3. $\mathbf{p H}$}

Pengujian $\mathrm{pH}$ dilakukan dengan alat pH meter. Pengujian ini mengacu pada metode yang dilakukan oleh Olfa, dkk., (2009). Pertama-tama sampel ditimbang sebanyak 10 gram, kemudian dihaluskan menggunakan mortar dan alu dengan menambahkan aquades 
sebanyak $100 \mathrm{ml}$ selama satu menit, sebelum dilakukan pengukuran bilas elektroda dengan aquades, kemudian keringkan dengan kertas tissue jika digunakan aquades, sebelum $\mathrm{pH}$ diukur, $\mathrm{pH}$ meter dikalibrasikan dengan buffer $\mathrm{pH} 4$ dan buffer $\mathrm{pH} 7$, Elektroda dibiarkan tercelup, sampai diperoleh pembacaan yang stabil, $\mathrm{pH}$ sampel yang terbaca pada layar dicatat.

\section{Analisis Statistika}

Penelitian dilaksanakan secara eksperimen menggunakan Rancangan Acak Lengkap (RAL) dengan tiga perlakuan yaitu lama perendaman sari jahe selama 10 menit (P1), 20 menit (P2) dan 30 menit (P3). Setiap perlakuan diulang sebanyak 6 kali, sehingga diperoleh 18 unit percobaan. Selanjutnya data daya ikat air, keempukan dan $\mathrm{pH}$ yang diperoleh diuji dengan menggunakan sidik ragam, jika hasil signifikan $\left(\mathrm{H}_{\mathrm{o}}\right.$ ditolak) maka dilanjutkan dengan Uji Jarak Berganda Duncan.

\section{Hasil Dan Pembahasan}

Pengaruh Perlakuan terhadap Kualitas Fisik (Daya Ikat Air, Keempukan dan pH) Daging Domba

Rataan pengaruh perlakuan lama perendaman terhadap kualitas fisik (daya ikat Air, keempukan dan $\mathrm{pH}$ ) daging domba disajikan pada Tabel 1 .

\section{Daya Ikat Air}

Nilai rata-rata daya ikat ikat pada perlakuan P3 (30,75 \%) merupakan hasil yang optimal dari perlakuan lainnya. Hasil penelitian menunjukkan bahwa lama perendaman memberikan pengaruh yang signifikan terhadap daging, yaitu memberikan waktu yang lebih lama bagi sari jahe yang mengandung enzim zingibain untuk bekerja, sehingga nilai DIA semakin meningkat.

Peningkatan DIA disebabkan adanya perubahan pada lemak dan protein dalam daging yang diakibatkan oleh enzim proteolitik yang bersumber dari sari jahe. Enzim proteolitik merusak membran otot sehingga terjadi difusi ion kedalam protein daging. Hal ini sesuai dengan pernyataan Soeparno (2011) yang menyatakan bahwa enzim-enzim proteolitik ikut bertanggung jawab atas perubahan membran sel otot. Degradasi struktur membran sel secara enzimatik menyebabkan difusi ion-ion kedalam wilayah yang mengelilingi protein-protein otot. Akhadiyah dan Santoso (2011) menambahkan jika terjadi difusi ion ke dalam protein daging maka akan terjadi pergantian ion divalensi (misalnya $\mathrm{Mg} 2+$ dan $\mathrm{Ca} 2+$ ) dengan ion monovalen pada rantai protein. Akibatnya pergantian kation divalent maka ion monovalen protein akan dapat mengikat air dan WHC dapat dipertahankan.

\section{Keempukan}

Berdasarkan Tabel 1. menunjukkan bahwa keempukan yang dihasilkan oleh perlakuan P1 $(52,90 \mathrm{~mm} / \mathrm{g} / 10 \mathrm{detik} /)$ berbeda nyata dengan perlakuan P2 $(71 \mathrm{~mm} / \mathrm{g} / 10$ detik/), hal tersebut diduga karena perendaman selama 20 menit menggunakan sari jahe yang mengandung enzim proteolitik telah bekerja secara optimal dalam menghidrolisis protein serat otot dan jaringan ikat daging domba. Hasil penelitian juga menunjukkan bahwa penambahan waktu untuk enzim bekerja akan menaikkan kecepatan reaksi (hidrolisis jarigan ikat), tetapi pada batas waktu tertentu tidak terjadi kenaikan jumlah jaringan ikat yang terhidrolisis walaupun waktu kerja enzim ditingkatkan.

Lama perendaman memberikan pengaruh yang siginifikan terhadap daging yaitu memberikan waktu yang lebih lama lagi bagi enzim proteolitik untuk bekerja. Hal ini sesuai dengan sistem kerja enzim yang dipengaruhi oleh konsentrasi enzim, suhu, $\mathrm{pH}$, inhibitor dan waktu. Waktu kontak atau reaksi antara enzim dan substrat menentukan efektivitas kerja enzim. Semakin lama waktu reaksi maka kerja enzim juga akan semakin optimum (Akhadiyah dan Santoso, 2011).

Keempukan daging domba disebabkan oleh terjadinya perubahan protein daging setelah daging direndam menggunakan sari jahe, dimana sari jahe ini mengandung enzim proteolitik yang biasa disebut dengan enzim zingibain. Enzim proteolitik bekerja aktif menghidrolisa protein muskulus penyusun stuktur daging, yaitu aktin dan miosin serta jaringan ikat yang terdiri dari kolagen, elastin, dan retikulin. Terurainya protein daging serta terpecahnya jaringan ikat maka akan memberikan tekstur yang lunak pada daging sehingga menjadi empuk. 
Tabel 1. Rangkuman Hasil Penelitian Pengaruh Lama Perendaman dengan Menggunakan Sari Jahe terhadap Kualitas Fisik (Kempukan, pH, dan Daya Ikat Air) Daging Domba

\begin{tabular}{llccc}
\hline Peubah & Satuan & \multicolumn{3}{c}{ Perlakuan } \\
\cline { 3 - 5 } & & P1 & P2 & P3 \\
\hline Daya Ikat Air & $(\%)$ & $20,88^{\mathrm{a}}$ & $22,16^{\mathrm{a}}$ & $30,75^{\mathrm{b}}$ \\
Keempukan & $(\mathrm{mm} / \mathrm{g} / 10$ detik $)$ & $51,90^{\mathrm{a}}$ & $71,80^{\mathrm{b}}$ & $63,07^{\mathrm{ab}}$ \\
pH & & $6,76^{\mathrm{a}}$ & $6,65^{\mathrm{a}}$ & $6,74^{\mathrm{a}}$ \\
\hline
\end{tabular}

Keterangan: Huruf kecil yang sama kearah horizontal menunjukkan tidak berbeda nyata

\section{pH}

Hasil sidik ragam yang diperoleh menunjukkan bahwa perlakuan berbagai lama perendaman sari jahe tidak berpengaruh nyata terhadap $\mathrm{pH}$ daging domba. Alasan yang dapat dikemukakan dalam penelitian ini karena $\mathrm{pH}$ awal jahe pada konsentrasi $15 \%$ yaitu 6,56 dimana nilai $\mathrm{pH}$ tersebut mendekati netral, sehingga ketika daging domba direndam oleh sari jahe dengan berbagai lama waktu perendaman maka tidak akan memberikan pengaruh yang nyata yaitu menghasilkan ph daging domba yang tidak berbeda jauh dengan pH sebelum direndam jahe sebesar 6,68.

Nilai $\mathrm{pH}$ sangat penting untuk diperhatikan karena $\mathrm{pH}$ dapat menunjukkan penyimpangan kualitas daging yang berkaitan dengan warna, keempukan, cita rasa, daya mengikat air dan masa simpan (Kuntoro, dkk., 2013). Rata-rata hasil penelitian berkisar antara 6,65-6,76, pada $\mathrm{pH}$ kisaran tersebut akan menghasilkan keempukan yang tinggi. Hal ini sesuai dengan pendapat Soeparno (2005) yang menyatakan bahwa kealotan daging sapi, daging domba dewasa-tua yang tertinggi dapat tercapai pada $\mathrm{pH}$ sekitar 5,9 tetapi keempukan meningkat dengan meningkatnya $\mathrm{pH}$ dari $6,0-$ 70 .

Kisaran $\mathrm{pH}$ penelitian berada diatas titik isoelektrrik sehingga terjadi peningkatan daya ikat air daging domba, hal ini sesuai dengan Soeparno (2005) bahwa DIA menurun dari $\mathrm{pH}$ tinggi 7-10 sampai pada $\mathrm{pH}$ titik isoelektrik protein-protein daging antara 5,05,1. Pada $\mathrm{pH}$ isoelektrik protein daging tidak bermuatan (jumlah muatan positif sama dengan jumlah muatan negatif) dan solubilitasnya minimal. Pada $\mathrm{pH}$ yang lebih tinggi dari $\mathrm{pH}$ isoelekrik protein daging, sejumlah muatan positif dibebaskan dan terdapat surplus muatan negatif yang mengakibatkan penolakan dari miofilamen dan memberi lebih banyak ruang untuk molekul air. Demikian pula pH lebih rendah dari titik isoelektrik protein-prtein daging, terdapat akses muatan positif yang mengakibatkan penolakan miofilamen dan memberi lebih banyak ruang untuk molekul-molekul air. Jadi pada $\mathrm{pH}$ lebih rendah atau lebih tinggi dari titik isoelektrik protein-protein daging, DIA meningkat.

\section{Kesimpulan Dan Saran Kesimpulan}

Berdasarkan hasil penelitian dan pembahasan maka dapat diambil kesimpulan bahwa:

1. Lama perendaman dengan menggunakan sari jahe memberikan pengaruh terhadap daya ikat air dan keempukan, namun tidak memberikan pegaruh terhadap $\mathrm{pH}$ daging domba.

2. Waktu perendaman yang optimal adalah 30 menit dengan nilai daya ikat air $(30,75$ $\%$, keempukan $(63,07 \mathrm{~mm} / \mathrm{g} / 10$ detik) dan $\mathrm{pH}(6,74)$ daging domba.

\section{Saran}

Perendaman daging dengan menggunakan sari jahe konsentrasi 15\% selama 30 menit dapat digunakan sebagai pengempuk daging baik di masyarakat maupun skala industri pada pengolahan daging.

\section{Ucapan Terima Kasih}

Penulis berterimakasih kepada semua pihak yang telah membantu dalam memfasilitasi penelitian ini sehingga selesai sesuai dengan yang diharapkan yaitu kepada Prof. Dr. Ir. Husmy Yurmiati, MS., sebagai Dekan sebagai Fakultas Peternakan Universitas Padjadjaran, dan kepada Prof. Dr. Ir. Kusmajadi Suradi, MS. Sebagai Kepala Laboratorium Teknologi Pengolahan Produk Peternakan. 


\section{Daftar Pustaka}

Akhadiyah, A. dan B. Santoso. 2011. Water Holding Capacity, Kadar Protein, Dan Kadar Air Dendeng Sapi Pada Berbagai Konsentrasi Ekstrak Jahe (Zingiber Officinale Roscoe) dan Lama Perendaman Yang Berbeda. Jurnal Ilmu dan Teknologi Hasil Ternak. 6 (2): 41-46.

Anna, P. dan F.M.T. Supriyanti. 2009. DasarDasar Biokimia. Universitas Indonesia Press, Jakarta. 155.

[BSN] Badan Standardisasi Nasional. 2008. [SNI] Standar Nasional Indonesia Nomor 3925: 2008. Mutu Karkas dan Daging Kambing/Domba. BSN, Jakarta.

Kuntoro, R.R.A. Maheswari dan H. Nuraini. 2013. Mutu Fisik dan Mikrobiologi Daging Sapi Asal Rumah Potong Hewan (RPH) Kota Pekanbaru. Jurnal Peternakan. 10(1): 4.

Lilis, S., W. S. Putranto, dan E. Wulandari. 2012. Pengaruh Perendaman Daging Itik Pada Berbagai Konsentrasi Ekstrak Kunyit (Curcuma domestika) Terhadap Warna, Rasa, Bau, dan pH. Jurnal Ilmu Ternak. 12 (1), Juni 2012 :24-28.

Olfa, M., Warnoto, D.B. Castika. 2009. Pengaruh Pemberian Jahe Merah (Zingiber officinale Rosc) terhadap Karakteristik Dendeng Daging Ayam Petelur Afkir. Jurnal Sain Peternakan Indonesia. 4(2):107-108.
Purbowati, C.I. Sutrisno, E. Baliarti, S.P.S. Budhi dan W. Lestariana. 2006. Karakteristik Fisik Otot Longissimus dorsi Dan Biceps femoris Domba Lokal Jantan Yang Dipelihara Di Pedesaan Pada Bobot Potong Yang Berbeda. Seminar Nasioanl Teknologi dan Veterniner. 13(2): 152.

Roswita, S. dan S. Usmiati. 2009. Karakteristik Daging Kambing Dengan Perendaman Enzim Papain. Seminar Nasional Teknologi Peternakan dan Veteriner 2009. 499506.

Soeparno. 2011. Ilmu Nutrisi Dan Gizi Daging. Gajah Mada University Press. Yogyakarta. 100. . 2005. Ilmu Dan Teknologi Daging. Gajah Mada University Press. Yogyakarta. 11-12; 290; 296-297; 289; 300.

Thompson, E.H, Wolf, dan Allen. 1973. Ginger Rhizome : A New Source Of Proteolytic Enzim, J. Food Sci. 38 (2) : 625-655.

Tien, R.M., Sugiyono, dan F. Ayustaningwarno. 2011. Ilmu Pengetahuan Bahan Pangan. PT. Alfabeta. Bandung. 6; 26; 28; 299. 